\title{
СПОСОБ ПРОГНОЗИРОВАНИЯ БАКТЕРИАЛЬНОГО ВУЛЬВОВАГИНИТА У ДЕВОЧЕК В ЗАВИСИМОСТИ ОТ СТАДИИ ПОЛОВОГО РАЗВИТИЯ СОГЛАСНО ШКАЛЕ ТАННЕРА
}

\author{
А. В. Казакова ${ }^{凶}$, Е. В. Уварова², Л. В. Лимарева ${ }^{1}$, А. А. Трупакова ${ }^{1}$, А. И. Мишина \\ ${ }^{1}$ Самарский государственный медицинский университет, Самара, Россия \\ ${ }^{2}$ Научный центр акушерства, гинекологии и перинатологии имени В. И. Кулакова, Москва, Россия
}

\begin{abstract}
На современном этапе мало научных работ по всестороннему изучению факторов, приводящих к вульвовагиниту у девочек. Целью исследования было разработать программу прогнозирования риска вульвовагинита у девочек в детском и подростковом возрасте. В исследовании приняли участие 252 здоровые девочки, которых разделили на группы в зависимости от стадии полового развития по Таннеру. У всех было проведено определение состава микрофлоры влагалища методом полимеразной цепной реакции (ПЦР) в режиме реального времени и распределение частот аллелей и генотипов полиморфных вариантов генов провоспалительных и противовоспалительных цитокинов. На основании полученных данных разработана рабочая модель по прогнозированию развития вульвовагинитов у девочек с учетом стадии полового развития. Благоприятными факторами для девочек на I стадии полового развития были преобладание облигатных анаэробов в микробиоте влагалища и гомозигота ТT полиморфного варианта гена IL10 (C-819T). Чувствительность модели составила 80\%, специфичность - 78\%. Для девочек в препубертатном и пубертатном периодах - преобладание аэробов в микробиоте влагалища и гомозигота ТT полиморфного варианта гена IL10 (C-3953T). Чувствительность модели составила 58,3\%, специсичность 94,1\%. С позиции доказательной медицины обоснована необходимость профилактических мероприятий в группах риска по развитию вульвовагинитов в детском возрасте, позволяющая снизить частоту рецидивов бактериального вульвовагинита в 3 раза
\end{abstract}

Ключевые слова: вульвовагинит, подростки, прогнозирование, профилактика, доказательная медицина

Информация о вкладе авторов: А. В. Казакова - концепция и дизайн исследования, сбор и обработка материала, статистическая обработка, написание и редактирование статьи; Е. В. Уварова - концепция и дизайн исследования, редактирование рукописи; Л. В. Лимарева - концепция и дизайн исследования, редактирование рукописи; А. А. Трупакова, А. И. Мишина - сбор и обработка материала, написание статьи.

Соблюдение этических стандартов: исследование одобрено этическим комитетом Самарского государственного медицинского университета (протокол № 5 от 20 апреля 2018 г.). Родители всех участников исследования подписали добровольное информированное согласие на анкетирование и медицинское вмешательство.

Для корреспонденции: Анна Владимировна Казакова, ул. Лесная, д. 31, кв. 40, г. Самара, 443110; amigo14021980@yandex.ru

Статья получена: 27.09.2019 Статья принята к печати: 17.10.2019 Опубликована онлайн: 29.10.2019

DOI: $10.24075 /$ vrgmu.2019.070

\section{PREDICTION OF BACTERIAL VULVOVAGINITIS IN GIRLS AT DIFFERENT TANNER STAGES OF SEXUAL DEVELOPMENT}

Kazakova $\mathrm{AV}^{1 \otimes}$, Uvarova EV², Limareva $\mathrm{LV}^{1}$, Trupakova $\mathrm{AA}^{1}$, Mishina $\mathrm{Al}^{1}$

1 Samara State Medical University, Samara, Russia

${ }^{2}$ Kulakov Federal Research Center for Obstetrics, Gynecology, and Perinatology, Moscow, Russia

At present, there is a paucity of research studies that comprehensively investigate the factors causing vulvovaginitis in young females. The aim of this work was to propose an algorithm for predicting the risk of vulvovaginitis in young girls and adolescents. The study recruited 252 healthy girls, who were stratified into a few groups depending on their sexual development on the Tanner scale. The composition of vaginal microbiota was determined in all the participants using realtime polymerase chain reaction (PCR); distribution of allele and genotype frequencies was assessed for the polymorphic variants of genes coding for pro- and anti-inflammatory cytokines. Based on the obtained data, we created a functional model for predicting the risk of vulvovaginitis in girls at different stages of sexual development. Favorable risk factors for Tanner I girls included predominance of obligate anaerobes in vaginal microbiota and the polymorphic IL10 variant (C-819T) homozygous for $\Pi$. The sensitivity of the model was $80 \%$, its specificity was $78 \%$. Favorable risk factors for prepubertal and pubertal girls included predominance of aerobes in the composition of vaginal microbiota and the presence of the TT allele in the polymorphic IL10 gene variant (C-3953T). The sensitivity of the model was $58.3 \%$, whereas specificity, $94.1 \%$. This study provides the rationale conforming with the principles of evidence-based medicine for using prevention measures in the groups at risk for vulvovaginitis at young age. The proposed measures allowed us to reduce the relapse rate of bacterial vulvovaginitis threefold.

Keywords: vulvovaginitis, teenagers, prediction, prevention, evidence-based medicine

Author contribution: Kazakova AV — study concept and design, data acquisition and analysis, manuscript draft; Uvarova EV — study concept and design, manuscript revision; Limareva LV — study concept and design, manuscript revision; Trupakova AA, Mishina Al — data acquisition and analysis, manuscript draft. Compliance with ethical standards: the study was approved by the Ethics Committee of Samara State Medical University (Protocol № 5 dated April 20, 2018). Informed consent was obtained from the parents of the study participants.

$\triangle$ Correspondence should be addressed: Anna V. Kazakova

Lesnaya, 31, kv. 40, Samara, 443110; amigo14021980@yandex.ru

Received: 27.09.2019 Accepted: 17.10.2019 Published online: 29.10.2019

DOI: $10.24075 /$ brsmu.2019.070

В последние годы происходят ухудшение показателей здоровья детей и подростков и рост числа нарушений репродуктивной системы игинекологическихзаболеваний [1-4]. О значимости проблемы воспалительной патологии гениталий свидетельствует ее высокая распространенность у детей всех возрастов [5-7]. Известно, что вульвовагинит является основным видом
(84,2\%) воспалительных заболеваний гениталий у девочек до 10 лет [8-10].

Основные факторы, способствующие развитию вульвовагинита в детском возрасте, - гормональный фон, особенности образа жизни, несоблюдение правил личной гигиены и генетические особенности иммунного реагирования [11-14]. Среди неблагоприятных факторов, 
влияющих на репродуктивное здоровье и вызывающих нарушение микробиоценоза влагалища, выделяют раннее начало половой жизни [15]. Еще большую опасность представляют самолечение и несвоевременное обращение в медицинские учреждения при возникновении гинекологических заболеваний.

Особенности местного иммунитета несомненно влияют на микробиоценоз влагалища и играют ведущую роль в развитии воспалительного ответа [16], но механизмы поддержания иммунной толерантности остаются малоизученными $[17,18]$

Гигиенические аспекты полового воспитания, несмотря на, казалось бы, достаточную научно-методическую проработанность, реализуются по-разному в различных регионах и социальных слоях. В отличие от генетических особенностей морфофункционального развития и иммунного реагирования, интимная гигиена и репродуктивное поведение являются модисицируемыми факторами, с помощью которых можно целенаправленно повлиять на состояние здоровья. Необходим поиск новых подходов к прогнозированию риска развития и обоснованному выбору профилактических мероприятий по предупреждению воспалительных заболеваний вульвы и влагалища в детском возрасте.

Целью исследования было разработать программу прогнозирования риска воспалительных заболеваний вульвы и влагалища в различные периоды полового созревания у девочек, для чего необходимо было определить социально-гигиенические, клиникоанамнестические, молекулярно-генетические маркеры, позволяющие прогнозировать развитие вульвовагинита разработать систему принятия решения для прогнозирования у девочек развития вульвовагинита; оценить клиническую эффективность программы профилактики воспалительных заболеваний вульвы и влагалища у девочек в зависимости от стадии полового развития.

\section{ПАЦИЕНТЫ И МЕТОДЫ}

Исследование проводили на базе детского поликлинического отделения № 1 Самарской городской поликлиники № 13 с февраля 2013 г. по август 2016 г. В исследовании приняли участие 252 здоровые девочки, проходившие профилактический осмотр на базе данного учреждения. Все участницы были разделены по группам в зависимости от возраста. Выбор возрастного интервала групп был обусловлен стадиями полового развития согласно шкале Таннера. Учитывая возрастные особенности, связанные с микробиоценозом влагалища, прогностические модели были созданы для групп девочек с разной стадией полового развития по Таннеру: первая группа - 74 девочки с І стадией полового развития, вторая группа - 178 девочек c II-V стадиями полового развития.

Критерии включения в исследование: возраст от 2 до 17 лет включительно; отсутствие субъективных жалоб; соматическое и гинекологическое здоровье; соответствие физического, полового и психического развития возрастным нормативам.

Критерии исключения: применение антибактериальных препаратов за месяц до обследования; наличие острых воспалительных заболеваний на момент осмотра и забора материала.

Все девочки и их матери были проанкетированы. В анкету входили вопросы о гигиенических навыках матерей и девочек, половом поведении подростков. Наряду с анкетированием провели клинико-лабораторное исследование 452 образцов биологического материала: 226 соскобов отделяемого слизистой оболочки влагалища, 226 образцов мазка с внутренней поверхности щеки.

Перед исследованием проводили оценку жалоб, физического (рост, масса тела, индекс массы тела) и полового развития (половая формула по Таннеру, данные наружного гинекологического осмотра), выявляли особенности гигиены наружных половых путей.

Образцы материала отбирали со слизистой оболочки преддверия влагалища или из заднего свода влагалища через гименальные кольца с помощью универсального зонда. ДНК условно-патогенных микроорганизмов (УМП) выявляли с помощью наборов реагентов Фемофлор-17 (ДНК-технология; Россия), предназначенных для исследования состояния биоценоза урогенитального тракта с детекцией результатов в режиме реального времени. Спектр диагностируемых показателей включал: контроль взятия материала (KВМ); общую бактериальную массу (ОБМ); наличие микоплазм (Mycoplasma hominis, Ureaplasma spp.), дрожжеподобных грибов (Candida spp.), бактерий (Lactobacillus spp., Enterobacterium spp., Streptococcus spp., Staphylococcus spp., Gardnerella vaginalis / Prevotella bivia / Porphyromonas spp., Eubacterium spp., Sneathia spp. / Leptotrichia spp. / Fusobacterium spp., Megasphaera spp. / Veillonella spp. / Dialister spp., Lachnobacterium spp. / Clostridium spp., Mobiluncus spp. I Corinebacterium spp., Peptostreptococcus spp., Atopobium vaginae), а также идентисикацию патогенов (Mycoplasma genitalium). Уровень КВМ был валиден во всех случаях, что подтверждает объективность последующего анализа полученных результатов.

Для выявления роли полиморфизма генов иммунного ответа в развитии и характере течения воспалительных заболеваний вульвы и влагалища и с учетом иммунного механизма развития данных патологий с помощью метода ПЦР были изучены особенности распределения у девочек частот аллелей и генотипов полиморфных вариантов генов провоспалительных и противовоспалительных цитокинов: IL1 $\beta$ (T-31C), IL1 $\beta$ (T-511C), IL1 $\beta(C-3953 T), ~ I L 1 \beta$ (G-1473C) в гене IL1 $\beta$; IL6 (C-174G) в гене IL6; TNF $\alpha$ (G-308A) в гене TNF $\alpha$; IL10 (G-1082A), IL10 (C-592A), IL10 (C-819T) в гене IL10; TGF $\beta 1$ (Arg25Pro) в гене TGF $\beta 1$.

Для построения деревьев решений использовали алгоритм CART (classification and regression tree - дерево классификации и регрессии). В алгоритме CART каждый узел дерева решений имеет двух потомков. На каждом шаге построения дерева формируемое в узле правило делило заданное множество наблюдений на две части часть, в которой выполнялось правило, и часть, в которой правило не выполнялось. Компьютерный алгоритм решал задачу, по какому признаку делать разбиение и по какому значению провести разбиение; когда остановить построение дерева. Для выбора оптимального правила использовали функцию оценки качества разбиения, основанную на индексе Джини (Gini) [19].

Для построения деревьев решений использовали следующие группы признаков:

- данные о влагалищной микробиоте, полученные с помощью системы Фемослор в грамм-эквивалентах и в процентном выражении относительно ОБМ;

- молекулярно-генетические исследования полиморфизмов генОВ цитокинов;

- особенности гигиены, полученные на основании анкетирования (интимная гигиена, прием душа, смена белья и др.). 
Дополнительно рассчитывали процентное соотношение двух групп микроорганизмов:

1) лактобактерий (аэробов);

2) облигатных анаэробов.

\section{Апробация профилактических рекомендаций}

Для апробации профилактических рекомендаций, сформированных на основании полученных данных, было проведено проспективное исследование с участием 167 девочек. Основная группа - 52 девочки, получавшие разработанные рекомендации, и 115 девочек группы контроля, получавшие общепринятые рекомендации детского гинеколога в обычном объеме. Наблюдательное исследование длилось в течение года, после чего был проведен статистический анализ с использованием методов доказательной медицины [20].

\section{Статистическая обработка полученных данных}

Сбор и хранение данных осуществляли в пакете Microsoft Excel. Для статистического анализа использовали специализированное программное обеспечение: SPSS 21 (IBM SPSS Statistics; USA, лицензия № 201306263 лицензия № 20130626-3). В качестве описательных статистик применяли среднее арифметическое и его ошибку $(\mathrm{M} \pm m)$ либо в случае скошенной формы распределения изучаемого признака - медиану и квартили. При анализе микроорганизмов в таблицах указывали, у скольких участниц выявлен данный вид, и его среднее содержание в виде десятичных логарифмов (lg). При этом средние значения вычисляли только по тем обследованным девочкам, у кого данные бактерии присутствовали. Для признаков, оцениваемых в номинальной шкале (заболевания в анамнезе, соблюдение гигиенических норм, генетические особенности), выполняли анализ таблиц сопряженности с расчетом критерия $\chi^{2}$ Пирсона.
Качество классификации оценивали с помощью ROC-кривых (характеристических кривых) и показателей доказательной медицины: чувствительности и специфичности.

\section{РЕЗУЛЬТАТЫ ИССЛЕДОВАНИЯ}

Учитывая возрастные особенности, связанные с микробиоценозом влагалища, построили прогностические модели развития вульвовагинита для групп девочек с разной стадией полового развития по Таннеру: первой группы (девочки с I стадией полового развития) и второй группы (девочки с II-V стадиями полового развития).

Прогностическая модель для девочек на I стадии полового развития представлена на рис. 1. Благоприятным фактором было наличие одновременно двух маркеров: преобладание облигатных анаэробов в микробиоте влагалища и гомозигота ТТ полиморфного варианта гена IL10 (C-819T). Нарушение хотя бы одного из этих условий, либо преобладание лактобацилл, либо присутствие хотя бы одного аллеля С в вышеназванном гене приводило к повышенному риску возникновения вульвовагинита у девочек первой группы.

Качество прогнозирования оценивали, построив таблицу сопряженности наблюдаемых и предсказанных моделью исходов (табл. 1). Получено 9 ложноположительных прогнозов (предсказан моделью вульвовагинит, а девочка оказалась здорова) и 3 - ложноотрицательных. Чувствительность метода для первой группы составила 80\%, специсричность - 78\%.

Согласно полученному дереву решений, прогнозирование осуществляли следующим способом.

1. Если процентное содержание аэробов было выше 34\%, то вероятным считали развитие вульвовагинита. Если процентное содержание аэробов было 34\% и менее, переходили к шагу 2

2. Если в гене IL10 в локусе 819 выявляли гомозиготное состояние по аллелю ТТ, то вероятность развития вульвовагинита считали минимальной. Если в гене IL10

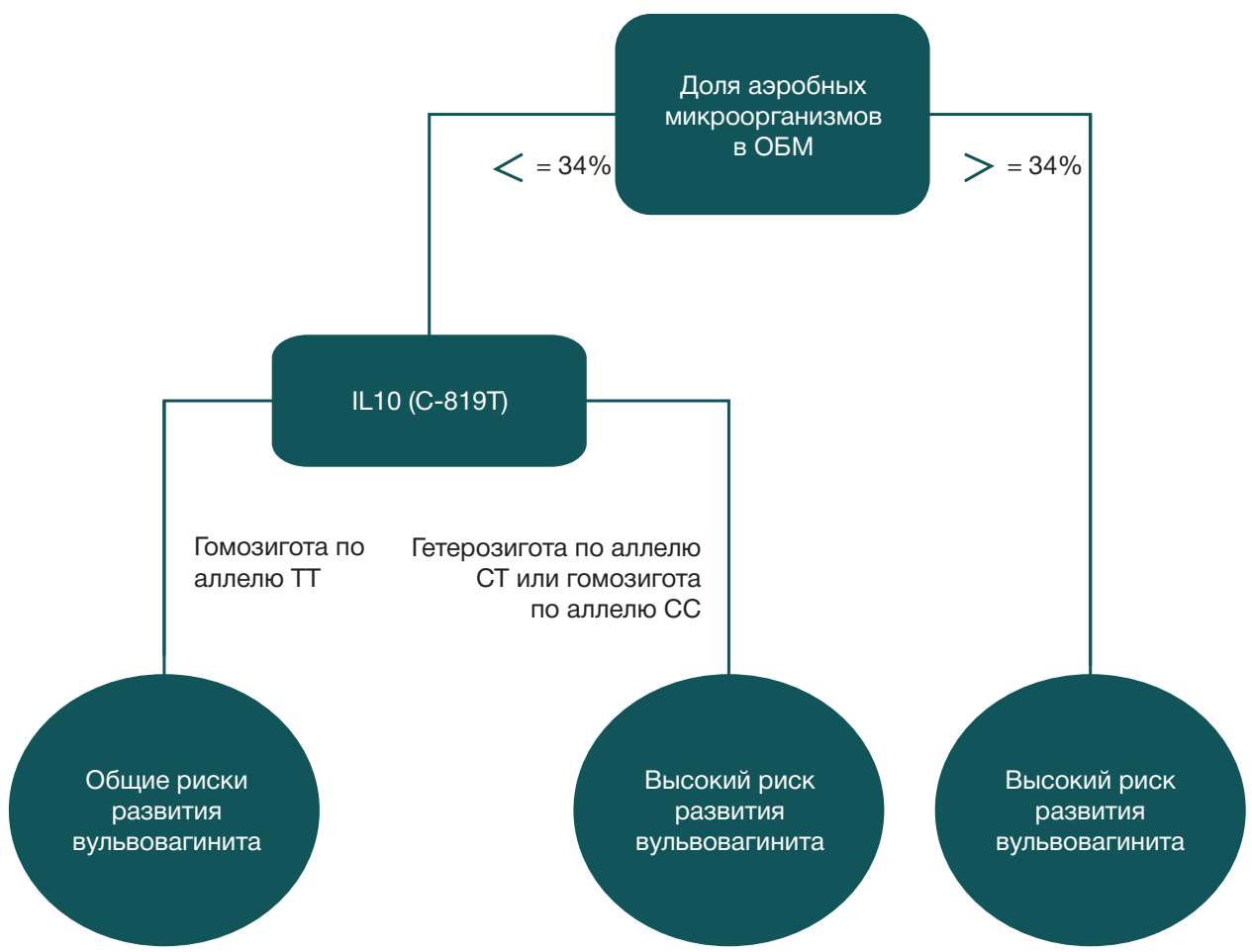

Рис. 1. Схема принятия решения по оценке риска бактериального вульвовагинита у девочек с І стадией полового развития по Таннеру 
Таблица 1. Качество прогнозирования

\begin{tabular}{|l|c|c|c|}
\hline \multirow{2}{*}{ Фактически } & \multicolumn{2}{|c|}{ Предсказано моделью } & Итого \\
\cline { 2 - 4 } & Здорова & Вульвовагинит & 41 \\
\hline Здорова & 32 & 9 & 15 \\
\hline Вульвовагинит & 3 & 12 & 56 \\
\hline Итого & 35 & 21 & 15 \\
\hline
\end{tabular}

в локусе 819 выявляли гомозиготное состояние по аллелю C (генотип СС) или гетерозиготное (генотип СТ), то вероятность развития вульвовагинита оценивали как высокую.

Прогностическая модель развития вульвовагинита для девочек при II-V стадии полового развития представлена на рис. 2. Благоприятными факторами в группе девочек в препубертатном и пубертатном периодах были преобладание аэробов в микробиоте влагалища и наличие гомозиготы ТТ полиморфного варианта гена IL10 (C-3953T). Нарушение хотя бы одного из этих условий (либо низкий уровень аэробов, либо присутствие хотя бы одного аллеля C В вышеназванном гене) приводило к повышенному риску развития вульвовагинита у девочек второй группы. Чувствительность полученных прогностических моделей составила 58,3\%, специсричность - 94,1\%.

Прогнозирование осуществляли следующим способом.

1. Если содержание аэробов в геном-эквивалентах оказывалось меньше или равно 6,15, переходили к шагу 2. Если содержание аэробов в геном-эквивалентах оказывалось больше 6,15, переходили к шагу 4.

2. Если в гене IL10 (полиморфизм C-592A) выявляли хотя бы один аллель А в гомо- или гетерозиготной форме, то вероятность развития вульвовагинита считали минимальной. Если в гене IL10 (полиморсиизм C-592A) выявляли генотип СС, то переходили к шагу 3.

3. Если девочка ежедневно принимала душ, то вероятность развития вульвовагинита была минимальной.
Если девочка принимала душ нерегулярно, то вероятность развития вульвовагинита была высокой.

4. Если в гене IL1 $\beta$ (полиморфизм C-3953T) выявляли генотип ТТ, то вероятность вульвовагинита была минимальной. Если в гене IL1 $\beta$ (полиморфизм C-3953T) выявляли генотип СТ или СС, то переходили к шагу 3.

Известно, что замена аллеля Т в позиции -3953 гена IL1 $\beta$ на аллель C приводит к более низкой продукции данного провоспалительного цитокина и клинически ассоциирована с менее интенсивным иммунным ответом на антиген. В сочетании с недостаточным уровнем гигиены это может стать решающим фактором в формировании воспалительного процесса.

При замене аллеля А в позиции -592 гена IL10 на аллель С происходит повышение продукции цитокина. Поскольку IL10 - противовоспалительный цитокин, повышение его синтеза на этапах реализации иммунного ответа при развитии инфекции также может привести к снижению эффективности механизмов иммунной защиты. Несмотря на факт генетической детерминированности повышенной продукции IL10, из полученного дерева решения следует, что эта потенциальная возможность реализуется лишь при гигиенических погрешностях.

Итак, применение алгоритма деревьев решений позволило создать удобную рабочую схему для оценки риска и проанализировать различные комбинации аллелей в их взаимосвязи.

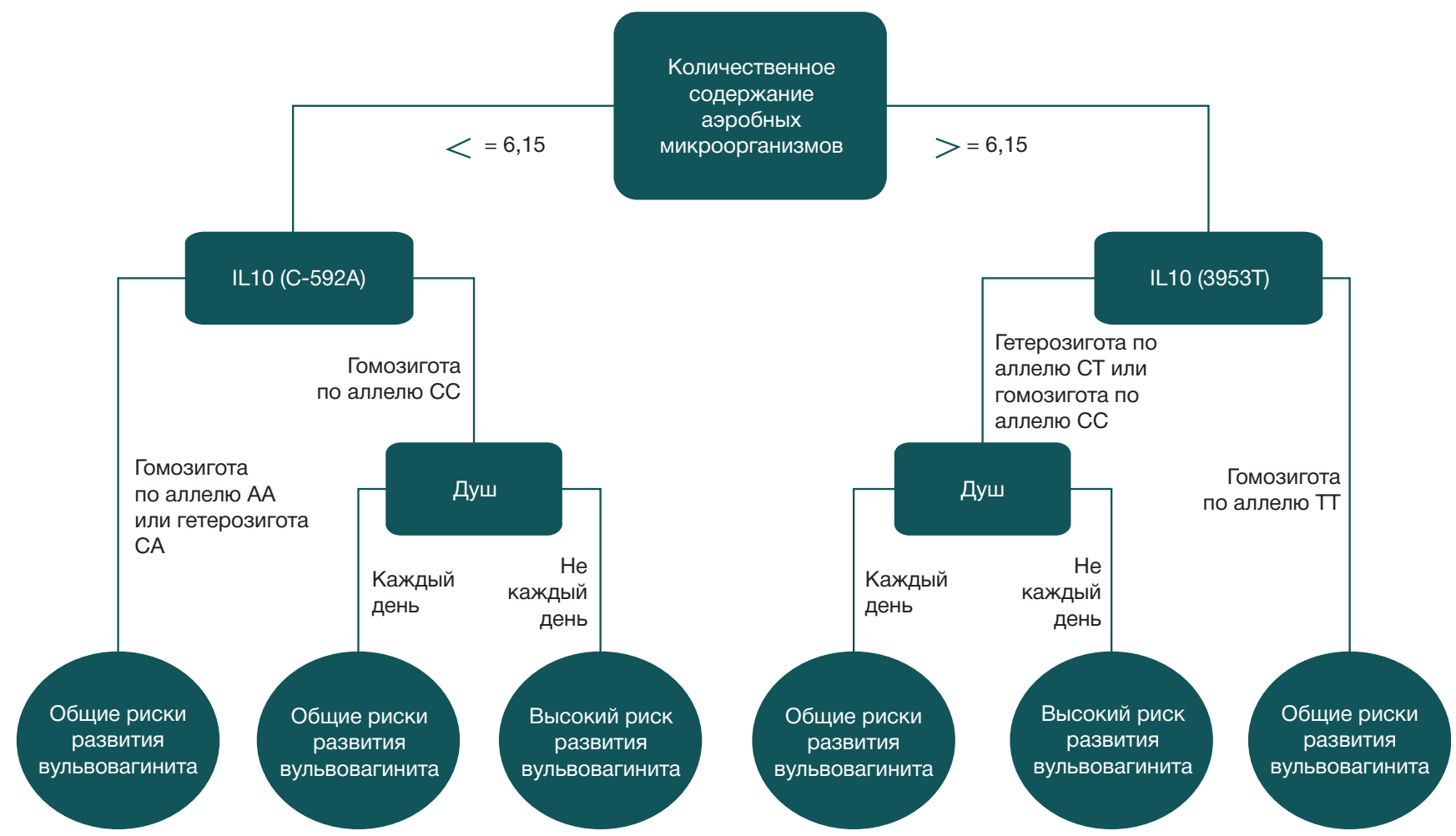

Рис. 2. Схема принятия решения по оценке риска неспецисических воспалительных заболеваний наружных половых путей у девочек со II-V стадиями полового развития по Таннеру 
На основании достоверных факторов риска, полученных в регрессионной модели, нами предложены следующие рекомендации для родителей и девочек в возрасте 16 лет и старше по профилактике воспалительных заболеваний вульвы и влагалища в группе риска по развитию вульвовагинита.

Для девочек с I стадией полового развития: 1) своевременная санация очагов инфекции (инфекционные заболевания мочевыделительной системы и ЛОРорганов), проведение курсов реабилитационного лечения специалистами при выявленных соматических заболеваниях; 2) ежедневный душ и смена белья; 3) интимная гигиена 2 раза в день; 4) наблюдение у гинеколога раз в год.

Для девочек co II-V стадиями полового развития: 1) при наличии аллергических заболеваний - коррекция и наблюдение врача-аллерголога; 2) ежедневный душ и смена белья; 3) интимная гигиена 2 раза в день; 4) дебют половой жизни после 17 лет; 5) безопасное сексуальное поведение: использование надежных методов контрацепции, один половой партнер; 6) наблюдение у гинеколога раз в год.

Для оценки эфффекта разработанной профилактической программы рассчитали ряд количественных показателей согласно рекомендациям Г. П. Котельникова, А. С. Шпигеля [20]. Предварительно составляли таблицу сопряженности применения дополнительных просилактических мероприятий и числа случаев с рецидивами (табл. 2).

Полученные в исследовании результаты представлены в табл. 3 и 4. Первые два базовых показателя, из которых осуществляли расчет эффективности вмешательства, частота исходов (рецидивов) в группах лечения (ЧИЛ) и контроля (ЧИК):

$$
\begin{aligned}
& \text { ЧИЛ }=a /(a+b) ; \\
& \text { ЧИК }=c /(c+d) .
\end{aligned}
$$

95\% ДИ для ЧИЛ и ЧИК рассчитаны по методу Уилсона. чИЛ составила 17,3\% (95\%ДИ: 9,4-29,7\%), ЧИК - 34,8\% (95\%ДИ: 26,7-43,9\%), $p=0,035$ по критерию $\chi^{2}$.

Насколько различаются частоты рецидива, оценивали на основании двух следующих показателей - снижении относительного и абсолютного риска (СОР и САР).

СОР - относительное уменьшение частоты рецидива в группе лечения по сравнению с контрольной группой:

$$
\mathrm{COP}=(4 И K-4 И Л) / 4 И K
$$

САР - разность частот рецидива между группами контроля и лечения:

$$
\mathrm{CAP}=4 И К-4 И Л .
$$

Расчет 95\% ДИ для СОР выполняли по методу М. Gardner, D. Altman, для CAP — по L. Bjerre, J. LeLorier [21, 22].

В данном исследовании частоты рецидива при проведении дополнительных профилактических мероприятий (ЧИЛ) снизились на 17,5\% (95\% ДИ: 2,7-29,5\%), т. е. вдвое:

$$
\mathrm{COP}=(34,8-17,3) / 34,8 \times 100 \%=50,2 \% .
$$

ОШ рецидива с ДИ, рассчитанным по J. Bland, D. Altman, составило 0,39 (95\% ДИ: 0,17-0,89).

В последующем рассчитывали число больных, которых необходимо лечить новым методом (ЧБНЛ), чтобы предотвратить неблагоприятный исход у одного больного. ЧБНЛ численно равно обратной величине САР (если

Таблица 2. Качество прогнозирования

\begin{tabular}{|l|c|c|}
\hline \multicolumn{1}{|c|}{ Группы } & Рецидив был & Рецидива не было \\
\hline Основная группа - реализация профилактической программы & $a$ & $b$ \\
\hline Контрольная группа - динамическое наблюдение & $c$ & $d$ \\
\hline Итого & $a+c$ & $c+d$ \\
\hline
\end{tabular}

Примечание: $a$ - рецидив был, $b$ - рецидива не было, $c$ - рецидив был, $d$ - рецидива не было.

Таблица 3. Результаты проведения профилактической программы

\begin{tabular}{|l|c|c|}
\hline \multirow{2}{*}{ Группы } & \multicolumn{2}{|c|}{ Эффект профилактической программы } \\
\cline { 2 - 3 } & Рецидив вульвовагинита & Рецидива вульвовагинита нет \\
\hline Основная группа - реализация профилактической программы & 9 & 43 \\
\hline Контрольная группа - динамическое наблюдение & 40 & 75 \\
\hline Итого & 49 & 115 \\
\hline
\end{tabular}

Таблица 4. Показатели, характеризующие эффект вмешательства

\begin{tabular}{|l|c|c|}
\hline \multicolumn{1}{|c|}{ Показатель } & Сокращение & Вычисленные значения, \% \\
\hline Частота исхода в группе лечения & чИЛ & 17,3 (9,4-29,7) \\
\hline Частота исхода в группе контроля & чИК & СОР $(26,7-43,9)$ \\
\hline Снижение относительного риска & САР (5,1-73,9) \\
\hline Снижение абсолютного риска & ЧБНЛ & $17,5(2,7-29,5)$ \\
\hline Число больных, которых необходимо лечить & ОР & $6(3-38)$ \\
\hline Относительный риск & ОШ & $0,5(0,26-0,95)$ \\
\hline Отношение шансов & $\chi^{2}$ & $0,39(0,17-0,89)$ \\
\hline$\chi^{2}$ с поправкой Йетса & $p$ & 4,47 \\
\hline$p$ & & 0,035 \\
\hline
\end{tabular}


САР выражен в процентах, то 100\% / САР), а его ДИ: величины, обратные границам 95\% ДИ: САР.

$$
\text { ЧБНЛ }=100 \% / \text { САР }=100 \% / 17,5 \%=6 .
$$

Это означает, что если шесть девочек из группы риска будут тщательно выполнять предложенные дополнительные более жесткие профилактические рекомендации, хотя бы одна из них гарантированно избежит развития вульвовагинита в течение ближайшего года. Следует отметить, что при данном объеме выборки ДИ: ЧБНЛ от 3 до 38 человек.

Сравнительный анализ частот рецидивов в группе, где проводили профилактические мероприятия, и статистических данных встречаемости вульвовагинитов в популяции также подтвердил эффективность предложенной просилактической программы. Из группы риска рецидивы развились в 17,4\% случаев (95\% ДИ по Клопперу-Пирсону составил 8,6-31,4\%). У 6 девушек в течение года наблюдали клиническую картину неспецифического вульвовагинита, а у 3 - патологическую степень чистоты в мазке. Эти показатели с высокой значимостью $(p<0,001)$ отличались от популяционных данных, согласно которым рецидивы воспалительных заболеваний нижних половых путей в данной возрастной группе развивались, в среднем, в $60 \%$ случаев $[23,24]$.

\section{ОБСУЖДЕНИЕ РЕЗУЛЬТАТОВ}

Полученные нами данные согласуются с результатами другого исследования, авторы которого определили, что данное состояние, как правило, бывает вызвано неспецифическими факторами, и наиболее эффективным при профилактике бактериального вульвовагинита является соблюдение гигиенических мероприятий [25].

Важность выбора средств и соблюдение правил гигиены наружных половых органов подчеркивает еще одно исследование, показавшее, что 25\% опрошенных используют спринцевание, 29\% - женские спреи, и 19\% - антисептические кремы в целях предотвращения ИППП, что увеличивает риск дисбиотических процессов во влагалище [26].

В кроссекционном исследовании, проведенном в Словакии, были определены наиболее частые нарушения интимной гигиены у девушек и молодых женщин 15-22 лет: полное удаление волос в интимной области (95\%), несоблюдение гигиенических процедур до и после полового акта (38\%), отсутствие смены мокрого купальника на сухой $(58,06 \%)$ и ношение непригодного нижнего белья. Респонденты более молодого возраста (15-18 лет), а также лица с более низким образовательным уровнем продемонстрировали худшие гигиенические навыки, которые могут быть связаны с более низкой осведомленностью [27].

Анализ литературы по проблеме нарушений микробиоценоза влагалища в детском возрасте показывает, что на современном этапе остается дискуссионным вопрос определения предикторов развития этой патологии.

Исследования, изучающие микрофлору влагалища в возрастном аспекте, разрознены и не всегда принимают во внимание индивидуальные возрастные "рамки» и не учитывают стадии становления репродуктивной системы.

Роль полиморфизма и экспрессии отдельных генов цитокинов в формировании данной патологии мало изучена.

Остаются актуальными всестороннее изучение и определение роли эндогенных (микробиота влагалища и полиморфизм генов иммунного ответа, особенности соматического здоровья) и экзогенных факторов (включая поведенческие аспекты) в развитии воспалительных заболеваний вульвы и влагалища.

\section{ВЫВОДЫ}

1. Разработанные прогностические модели развития воспалительных заболеваний половых путей с учетом стадий полового развития по Таннеру целесообразно использовать для принятия решения по выбору лечебно-профилактических мероприятий у девочек в возрасте от 2 до 17 лет. 2. С позиции доказательной медицины обоснована необходимость профилактических мероприятий в группах риска по развитию воспалительных заболеваний вульвы и влагалища в детском возрасте, позволяющая снизить частоту рецидивов бактериального вульвовагинита в 3 раза. 3. Интерес представляет дальнейшее совершенствование алгоритма профилактики воспалительных заболеваний наружных половых путей в детском возрасте с применением современных компьютерных программ и выделением групп риска на основе персонализированного подхода.

\section{Литература}

1. Alvarez-Olmos $\mathrm{Ml}$, et al. Vaginal lactobacilli in adolescent: presence and relationship to local and systemic immunity, and to bacterial vaginosis. Sex Transm Dis. 2004; (31): 393-400.

2. Amjadi $F$, et al. Role of the innate immunity in female reproductive tract. Adv Biomed Res. 2014; (3): 1

3. Attieh E, Maalouf S, Roumieh D, et al. Feminine hygiene practices among female patients and nurses in Lebanon. Reproductive Health. 2016; 13 (1): 59.

4. Beyiter I, Kavukcu S. Clinical presentation, diagnosis and treatment of vulvovaginitis in girls: a current approach and review of the literature. World J Pediatr. 2017; 13 (2): 101-5.

5. Казакова А. В. Программа профилактики бактериального вульвовагинита у девочек в зависимости от стадии полового развития [диссертация]. Самара, 2019.

6. Прилепская В. Н., Летуновская А. Б., Донников А. Е. Микробиоценоз влагалища и полиморфизм генов цитокинов

как маркер здоровья женщины. Гинекология. 2015; (2): 4-13.

7. Altun I, Cinar ND, Dede C. Hygiene behaviour in university students in Turkey. J Pak Med Assoc. 2013; 63 (5): 585-9.

8. Гриневич Е. В. Характеристика микробиоценозов влагалища, кишечника и мочевыводящих путей при вульвовагинитах у девочек раннего возраста в зависимости от различных факторов риска [диссертация]. Смоленск, 2005.

9. Казакова А. В., Спиридонова Н. В., Уварова Е. В., Комарова М. В., Безрукова А. А. Многомерный анализ предикторов патологических выделений из половых путей в зависимости от образа жизни студенток. Репродуктивное здоровье детей и подростков. 2016; (6): 90-7.

10. Чеботарева Ю. Ю., Костоева З. А., Григорян А. А. Анатомофункциональные особенности репродуктивной системы при вульвовагинитах у часто болеющих детей. Кубанский научный медицинский вестник. 2013; (1): 178-81. 
11. Karlsson CL, Molin G, Cilio CM, et al. The pioneer gut microbiota in human neonates vaginally born at terma pilot study. Pediatr Res. 2011; (70): 282-6.

12. Kayserova J, et al. Serum immunoglobulin free light chains in severe forms of atopic dermatitis. Clin Immunol. 2010; (71): 312-6.

13. Kestřánek J, Jílek $P$, Matula $V$, et al. Jaký je aktuální stav diagnostiky vulvovaginálního dyskomfortu $\vee$ České Republice? Česká Gynekologie. 2013; 78 (6): 522-7.

14. Mitchell C, Moreira C, Fredricks D, et al. Detection of fastidious vaginal bacteria in women with HIV infection and bacterial vaginosis. Infectious Diseases in Obstetrics and Gynecology. 2009; (12) Access mode: https://www.ncbi.nlm.nih.gov/pmc/ articles/PMC2777244/. (Date of access: 22.10.19).

15. Жижко Е. В., Чигановой С. Д. Молодая семья: проблемы и перспективы социальной поддержки. Красноярск: РУМЦ ЮO, 2011; 145 c.

16. Fischer GO. Chronic vulvitis in prepubertal girls. Aust $J$ Dermatology. 2010; (51): 118-23.

17. Lewis WG, Robinson LS, Perry J, et al. Hydrolysis of secreted sialoglycoprotein immunoglobulin A $(\operatorname{IgA})$ in ex vivo and biochemical models of bacterial vaginosis. J Biol Chem. 2012; 287 (3): 2079-89.

18. Ott MA, Ofner S, Fortenberry JD. Beyond douching: use of feminine hygiene products and STI risk among young women. J Sex Med. 2009; (6): 1335-40.

19. Кохреидзе Н. А., Гуркин Ю. А., Кутушева Г. Ф. и др.
Вульвовагинит в раннем детстве. СПб., 2017; 23 с.

20. Зиядуллаев У. Х. Состояние иммунитета при кандидозном вульвовагините у девочек подростков. Проблемы репродукции. 2014; (2): 32-4.

21. Gardner M J, Altman DG. Statistics with confidence. BMJ publications. Reprint. 1994: 51-52.

22. Bjerre LM, LeLorier J. Expressing the magnitude of adverse effects in case-control studies: "the number of patients needed to be treated for one additional patient to be harmed". BMJ. 2000; (320): 503-6.

23. Здравоохранение в России. 2017: Статистический сб. Росстат. Москва, 2017; 170 с. Доступно по ссылке: [http:// www.gks.ru/free_doc/doc_2017/zdrav17.pdf].

24. Кириллова Е. Н., Павлюкова С. А. , Акулич Н. С. Вульвовагинит у детей. Медицинский журнал. 2017; (2): 151-3.

25. Brabin $L$, Roberts $S A$, Fairbrother E, et al. Factors affecting vaginal $\mathrm{pH}$ levels among female adolescents attending genitourinary medicine clinics. Sex Transm Infect. 2005; (81): 483-7.

26. Brotman RM, Erbelding EJ, Jamshidi RM, et al. Findings associated with recurrence of bacterial vaginosis among adolescents attending sexually transmitted diseases clinics. J Pediatr Adolesc Gynecol. 2007; (20): 225-31.

27. Donders GG, et al. Vaginal cytokines in normal pregnancy. American journal of obstetrics and gynecology. 2003; (189): $1433-8$

\section{References}

1. Alvarez-Olmos $\mathrm{Ml}$, et al. Vaginal lactobacilli in adolescent: presence and relationship to local and systemic immunity, and to bacterial vaginosis. Sex Transm Dis. 2004; (31): 393-400.

2. Amjadi $F$, et al. Role of the innate immunity in female reproductive tract. Adv Biomed Res. 2014; (3): 1.

3. Attieh $E$, Maalouf $S$, Roumieh $D$, et al. Feminine hygiene practices among female patients and nurses in Lebanon. Reproductive Health. 2016; 13 (1): 59.

4. Beyiter I, Kavukcu S. Clinical presentation, diagnosis and treatment of vulvovaginitis in girls: a current approach and review of the literature. World J Pediatr. 2017; 13 (2): 101-5.

5. Kazakova A. V. Programma profilaktiki bakterial'nogo vul'vovaginita $u$ devochek $v$ zavisimosti ot stadii polovogo razvitija [dissertacija]. Samara, 2019. Russian.

6. Prilepskaya VN, Letunovskaya AB, Donnikov AE. Mikrobiocenoz vlagalishha i polimorfizm genov citokinov kak marker zdorov'ja zhenshhiny. Ginekologija. 2015; (2): 4-13. Russian.

7. Altun I, Cinar ND, Dede C. Hygiene behaviour in university students in Turkey. J Pak Med Assoc. 2013; 63 (5): 585-9.

8. Grinevich EV. Harakteristika mikrobiocenozov vlagalishha, kishechnika i mochevyvodjashhih putej pri vul'vovaginitah u devochek rannego vozrasta $v$ zavisimosti ot razlichnyh faktorov riska [dissertacija]. Smolensk, 2005. Russian.

9. Kazakova AV, Spiridonova NV, Uvarova EV, Komarova MV, Bezrukova AA. Mnogomernyj analiz prediktorov patologicheskih vydelenij iz polovyh putej v zavisimosti ot obraza zhizni studentok. Reproduktivnoe zdorov'e detej i podrostkov. 2016; (6): 90-7. Russian.

10. Chebotareva YuYu, Kostoeva ZA, Grigorjan AA. Anatomofunkcional'nye osobennosti reproduktivnoj sistemy pri vul'vovaginitah u chasto bolejushhih detej. Kubanskij nauchnyj medicinskij vestnik. 2013; (1): 178-81. Russian.

11. Karlsson CL, Molin G, Cilio CM, et al. The pioneer gut microbiota in human neonates vaginally born at terma pilot study. Pediatr Res. 2011; (70): 282-6.

12. Kayserova J, et al. Serum immunoglobulin free light chains in severe forms of atopic dermatitis. Clin Immunol. 2010; (71): 312-6.

13. Kestřánek J, Jílek $P$, Matula $V$, et al. Jaký je aktuální stav diagnostiky vulvovaginálního dyskomfortu $\vee$ České Republice? Česká Gynekologie. 2013; 78 (6): 522-7.

14. Mitchell C, Moreira C, Fredricks D, et al. Detection of fastidious

vaginal bacteria in women with HIV infection and bacterial vaginosis. Infectious Diseases in Obstetrics and Gynecology. 2009; (12) Access mode: https://www.ncbi.nlm.nih.gov/pmc/ articles/PMC2777244/. (Date of access: 22.10.19).

15. Zhizhko EV, Chiganovoj SD. Molodaja sem'ja: problemy i perspektivy social'noj podderzhki. Krasnojarsk: RUMC JuO, 2011; 145 s. Russian.

16. Fischer GO. Chronic vulvitis in prepubertal girls. Aust $J$ Dermatology. 2010; (51): 118-23.

17. Lewis WG, Robinson LS, Perry J, et al. Hydrolysis of secreted sialoglycoprotein immunoglobulin A ( $\operatorname{lgA})$ in ex vivo and biochemical models of bacterial vaginosis. J Biol Chem. 2012; 287 (3): 2079-89.

18. Ott MA, Ofner S, Fortenberry JD. Beyond douching: use of feminine hygiene products and STI risk among young women. J Sex Med. 2009; (6): 1335-40.

19. Kohreidze NA, Gurkin YuA, Kutusheva GF, i dr. Vul'vovaginit v rannem detstve. SPb., 2017; 23 s. Russian.

20. Zijadullaev UH. Sostojanie immuniteta pri kandidoznom vul'vovaginite $u$ devochek podrostkov. Problemy reprodukcii. 2014; (2): 32-4. Russian.

21. Gardner MJ, Altman DG. Statistics with confidence. BMJ publications. Reprint. 1994: 51-52.

22. Bjerre LM, LeLorier J. Expressing the magnitude of adverse effects in case-control studies: "the number of patients needed to be treated for one additional patient to be harmed". BMJ. 2000; (320): 503-6.

23. Zdravoohranenie v Rossii. 2017: Statisticheskij sb. Rosstat. Moskva, 2017; 170 s. Dostupno po ssylke: [http://www.gks.ru/ free_doc/doc_2017/zdrav17.pdf]. Russian.

24. Kirillova EN, Pavlyukova SA, Akulich NS. Vul'vovaginit u detej. Medicinskij zhurnal. 2017; (2): 151-3. Russian.

25. Brabin L, Roberts SA, Fairbrother E, et al. Factors affecting vaginal $\mathrm{pH}$ levels among female adolescents attending genitourinary medicine clinics. Sex Transm Infect. 2005; (81): 483-7.

26. Brotman RM, Erbelding EJ, Jamshidi RM, et al. Findings associated with recurrence of bacterial vaginosis among adolescents attending sexually transmitted diseases clinics. J Pediatr Adolesc Gynecol. 2007; (20): 225-31.

27. Donders GG, et al. Vaginal cytokines in normal pregnancy. American journal of obstetrics and gynecology. 2003; (189): 1433-8. 